Elżbieta Czerwińska

e.czerwinska@po.opole.pl

Anna Jańdziak

a.jandziak@po.opole.pl

Biblioteka Główna Politechniki Opolskiej

\title{
INNOWACYJNOŚĆ W BIBLIOTECE - DOŚWIADCZENIA BIBLIOTEK EUROPEJSKICH
}

\begin{abstract}
The article discusses the reasons for the decrease in inter est in the traditional library. The solutions proposed in the literature of the subject and examples of practical solutions used in European libraries are presented.
\end{abstract}

Slowa kluczowe: innowacje, usługi biblioteczne, użytkownicy, przestrzeń publiczna

\section{Wstęp}

Od kilku lat biblioteki odnotowują systematyczne zmniejszanie się liczby odwiedzin użytkowników. Tendencję spadkową potwierdzają przeprowadzone w 2015 r. badania w Stanach Zjednoczonych, które wykazały również, że blisko 25\% użytkowników odwiedzających bibliotekę nie orientowało się w pełnej ofercie jej usług ${ }^{1}$. Statystyki te powodują często ograniczania zakupów i usług, redukcję etatów oraz restrukturyzację biblioteki, na przykład likwidację bibliotek wydziałowych i tworzenie scentralizowanych zasobów informacyjnych dla całego kampusu. Aby biblioteka zaczęła znów przyciągać czytelników konieczne jest przedefiniowanie jej misji społecznej, celów i szukanie innowacyjnych podejść do zagospodarowania przestrzeni i wyposażenia.

\section{Spadek zainteresowania tradycyjną biblioteką - analiza problemu}

„Wśród przyczyn spadku zainteresowania tradycyjną ofertą bibliotek wymienia się:

- rozwój usług teleinformacyjnych - większość bibliotek oferuje swoim użytkownikom usługi i zasoby dostępne online, z których czytelnik

${ }^{1}$ J. A. McArthur, V. J. Graham, User-experience design and library spaces: a pathway to innovation?, „Journal of Library Innovation” 2015, vol. 61, no 2, s. 1-14. 
może korzystać z dowolnego miejsca na świecie i o dowolnym czasie. Badania w amerykańskich uczelniach wykazały, że każda ze 100 ankietowanych bibliotek uczelnianych oferuje od 1 do 7 mobilnych serwisów, przy czym najwięcej z nich (46\%) - 6 rodzajów, a wszystkie świadczą usługi informacji naukowej przez czat. Mobilny dostęp do ebooków zapewnia $92,6 \%$ badanych instytucji, do OPAC - 88\%, baz danych - 81,7\%, stron WWW - 81,6\%, informacji przez SMS - 77,2\%, szkoleń bibliotecznych - 32,35\%, wypożyczeń międzybibliotecznych - 20,5\%. Kody QR wykorzystuje 77,2\% bibliotek, mobilne aplikacje na stronie - 29,2\%, a rozszerzoną rzeczywistość - 5\%. Najpopularniejsze funkcje i treści mobilnych wersji stron WWW to przeszukiwanie katalogu (96,6\%), dane teleadresowe biblioteki $(96,6 \%)$ przeszukiwanie baz danych (70\%), prolongata wypożyczeń $(56,6 \%)$, dostęp do kont czytelników $(53,3 \%)$ i wypożyczenia międzybiblioteczne $(26,6 \%)$. Wśród najchętniej używanych technologii znalazła się także aplikacja wykorzystywana do dostępu do e-czasopism, część bibliotek wdraża także własne oprogramowanie, część - aplikacje dostarczane przez dostawców urządzeń i treści²;

- $\quad$ zasoby Internetu - biblioteki szkół wyższych nie stanowią obecnie dla środowisk akademickich i naukowych podstawowego źródła dostępu do informacji. Dane dostępne na stronach WWW różnych instytucji, organizacji czy osób fizycznych pozwalają dotrzeć do potrzebnych informacji z pominięciem bibliotek ${ }^{3}$;

- niż demograficzny, skutkujący stale zmniejszającą się liczbą osób rozpoczynających studia;

- niewystarczające środki na zbiory oraz wyposażenie - Claire Nguen w swoim artykule ${ }^{4}$ przedstawia, że na przestrzeni lat 2012-2014 trudności finansowe zmusiły liczne francuskie biblioteki uniwersyteckie do zmniejszenia liczby zakupionych książek o blisko $25 \%$, a prenumeraty (bądź z bezpośredniego zakupu) elektronicznych i drukowanych czasopism, książek naukowych oraz baz danych o $20 \%$. Clara Nguen analizuje również wzrost cen czasopism. W latach 1986-2004 ceny wzrosły aż o $273 \%$, a co za tym idzie prenumerata czasopism w niektórych bibliotekach pochłaniała nawet $2 / 3$ budżetu;

${ }^{2}$ Y.Q. Liu, S. Briggs, A library in the palm of your hand: mobile services in top 100 university libraries, „Information Technology and Libraries” 2015, vol. 34, no 2, s. 134, https:// ejournals.bc.edu/ojs/index.php/ital/article/view/5650/pdf, [dostęp: 26.08.2016].

${ }^{3} \mathrm{Z}$. Yi, Effective techniques for the promotion of library services and resources, „Information Research” 2016, vol. 21, no 1, s. 702, http://www.informationr.net/ir/21-1/ paper702.html\#.WP3P_qI3lw4, [dostęp: 16.03.2017].

${ }^{4} \mathrm{C}$. Nguyen, Les bibliothèques universitaires se désabonnent, „Documentalist - Sciences de l'information" 2014, vol. 51, no 3, s. 9-11. 
- zmieniające się potrzeby i oczekiwania użytkowników - biblioteka jest obecnie postrzegana przede wszystkim jako obiekt użyteczności publicznej i realizacji takich funkcji oczekują jej obecni i potencjalni użytkownicy.

\section{Spadek zainteresowania tradycyjną biblioteką - propozycje rozwiązań $w$ literaturze przedmiotu}

Naukowcy prowadzą badania nad znalezieniem recepty na zmniejszające się zainteresowanie bibliotekami. Autorzy pracy Public libraries in the Knowledge Society: core services of libraries in Informational World Cities dowodzą, że ważne są dwie funkcje biblioteki:

- $\quad$ wspieranie społeczności lokalnej, firm i władz samorządowych poprzez zapewnianie zasobów i usług cyfrowych oraz komunikację przez sieć 2.0;

- oferowanie przyjaznych i atrakcyjnych przestrzeni do nauki, spotkań i pracy oraz stref dostosowanych do potrzeb różnych grup odbiorców w wielofunkcyjnym budynku będącym wizytówką miasta i ikoną architektury ${ }^{5}$.

John A. McArthur i Valerie Johnson Graham zwracają uwagę na ich zdaniem ważne czynniki jakimi są elementy wpływające na budzenie trwałych, pozytywnych emocji. Chodzi o stworzenie środowiska pomiędzy bibliotekarzami a czytelnikami utrwalającego pozytywne doznania, emocje, a zarazem pozwalającego na stworzenie relacji łączących ludzi między sobą, a także pozytywne przeżycia związane z biblioteką oraz umożliwiającego dzielenie się emocjami i samorealizację. Do realizacji tych zadań można wykorzystać serwisy społecznościowe, zapisywanie, nagrywanie i publikowanie miłych wspomnień dotyczących biblioteki i tworzenie grupy a mbasadorów biblioteki, czyli osób związanych z nią emocjonalnie i przygotowanych do propagowania jej usług ${ }^{6}$.

Amerykańskie Stowarzyszenie Bibliotek (ALA) w raporcie New State of America's Libraries Report finds shift in role of U.S. libraries $^{7}$ mówi o zmianie sposobu postrzegania bibliotek wszystkich typów przez opinię publiczną.

\footnotetext{
${ }^{5}$ A. Mainka, S. Hartmann, L. Orszullok, I. Peters, A. Stallman, W. G. Stock, Public libraries in the Knowledge Society: core services of libraries in Informational World Cities, „Libri” 2013, vol. 63, no 4, s. 295-319.

${ }^{6} \mathrm{~J}$. A. McArthur, V. J. Graham, User-experience design and library spaces: a pathway to innovation?, „Journal of Library Innovation” 2015, vol. 6, no 2, s. 1-14.

${ }^{7}$ M. Morales, New State of America's Libraries Report finds shift in role of U.S. libraries, www.ala.org/news/press-releases/2015/04/new-state-america-s-libraries-report-finds-shift-role-us -libraries, [dostęp: 16.04.2016].
} 
Coraz rzadziej dostrzegana jest usługa udostępniania książek, a coraz częściej biblioteki są postrzegane jako istotne dla rozwoju gospodarczego danego regionu, centra akademickiej aktywności, przyjazne miejsca mające pozytywny wpływ na lokalne społeczności, szkoły i kampusy akademickie. Wśród nowych zadań bibliotek wymieniono: tworzenie środowisk edukacyjnych umożliwiających uczenie się w dowolnie wybranym czasie, podnoszenie kwalifikacji informacyjnych użytkowników, pomoc w analizie zbiorów danych o dużej objętości (big data) oraz wspieranie wymiany i ponownego wykorzystywania danych badawczych.

Joachim Schopfel, Julien Roche, i Gilles Hubert w artykule Co-working and innovation: new concepts for academic libraries and learning centres ${ }^{8}$ sukcesu bibliotek uczelnianych dopatrują się w rozszerzeniu zakresu swoich usług o aspekty związane z szeroko rozumianą pracą. Biblioteki mając duże powierzchnie, a także bogatą sieć społecznościową użytkowników mogą aktywnie włączyć się w nurt coworkingu, tworząc centra kształcenia (learning centre), w których następowałby transfer wiedzy, transfer technologii między nauką a biznesem. Biblioteka ma być nie tylko miejscem przyjaznym, gdzie studenci będą czuć się dobrze, gdzie można wypić kawę, porozmawiać z kolegami, ale również miejscem, gdzie można zdobyć nowe, w tym przede wszystkim zawodowe kompetencje, gdzie można spotkać się z doradcą zawodowym, finansowym, uzyska się pomoc przy przygotowaniu CV i w autopromocji, a także możliwość uczenia się od pracodawców i specjalistów, tworzenia sieci kontaktów zawodowych i temu podobnych.

\section{Przykłady praktycznych rozwiązań w bibliotekach europejskich Biblioteka jako centrum społeczności i prekursor integracji cyfrowej (Biblioteka w Köln) ${ }^{9}$}

W 2013 r. w bibliotece pojawiała się drukarka 3D i program kreatywnych warsztatów jej obsługi. Takie podejście rozpoczęło proces zmiany wizerunku placówki i charakteru jej pracy. Książka przestała być najważniejszym elementem w bibliotece, obecnie stanowi jedynie część działalności biblioteki. Pracownicy $\mathrm{w}$ kreatywny sposób włączają się $\mathrm{w}$ pracę $\mathrm{z}$ czytelnikiem.

${ }^{8}$ J. Schopfel, J. Roche, G. Hubert, Co-working and innovation: new concepts for academic libraries and learning centres, „New Library World” 2015, vol. 116, no 1/2, s. 67-78.

${ }^{9}$ Nowe koncepcje - nowe biblioteki. Praktyczne przykłady z czterech krajów europejskich, http://www.instytutksiazki.pl/upload/Files/bnowaII_warszawa_podsumowanie.pdf, [dostęp: 16.03. 2017]. 
Koniecznym było przestawienie się z modelu pracy: pracownik - zasoby na pracownik - użytkownik. Biblioteka zaproponowała użytkownikom różne, czasem nietypowe formy działalności obejmujące:

1. Organizację mini-bibliotek w parkach czy centrach handlowych (jest to model biblioteki zasugerowany oddolnie przez użytkowników). Takie punkty obsługują wolontariusze, wypożyczanie odbywa się na zasadzie wzajemnego zaufania, bez zbędnych formalności. Do mini-bibliotek wraca $70 \%$ wypożyczonych książek.

2. Uruchamianie automatów bibliotecznych na stacjach metra.

3. Oferowanie usług cyfrowych, takich jak:

- $\quad$ wypożyczanie książek elektronicznych, tabletów, czytników elektronicznych, urządzeń nawigacyjnych;

- $\quad$ organizacja warsztatów odkrywających świat cyfryzacji prowadzone przez specjalistów, wolontariuszy oraz pracowników biblioteki;

- umożliwienie korzystania z robotów i gier komputerowych;

- zakup najnowocześniejszego sprzętu (drukarka 3D, gogle Oculus Rift 2, iPody ze specjalnymi aplikacjami, które łudząco przypominają książki obrazkowe);

- $\quad$ ogólnodostępna sieć WiFi.

4. Uruchomienie Infopunktów, czyli punktów informacyjnych zamiast tradycyjnych lad bibliotecznych.

5. Stworzenie przestrzeni pod nazwą Markerspace, czyli miejsce twórcy, w którym użytkownik może rozwijać swoje umiejętności i zdobywać nowe kompetencje.

6. Zacieśnianie więzi między pokoleniami poprzez:

- $\quad$ kawiarenkę pracy domowej, w której odrabia się zadania domowe osoby starsze pomagają dzieciom w lekcjach, a dzieci uczą dorosłych obsługi programów komputerowych;

- $\quad$ robótki ręczne - zajęcia, na których panie robią na drutach czy szydełku, następnie sprzedają swoje wyroby, a zarobione pieniądze przeznaczają na zajęcia $\mathrm{z}$ technik komputerowych;

- $\quad$ kreatywny program dla dzieci: Lego Mindstrom, kodowanie i programowanie robota Finch, Digital story - cyfrowe snucie opowieści, Marker Day - praktyczne łączenie technologii z elementami życia codziennego.

7. Inne nieszablonowe działania wpływające na budowanie wizerunku:

- Geeks@Cologne - program dla młodych osób, które chcą poznawać kolegów, przyjaciół przy kreatywnym działaniu; 
- $\quad$ slamy naukowe - wydarzenia, podczas których młodzi ludzie mają 10 minut na zaprezentowanie swojej pracy lub wyników badań;

- $\quad$ koncerty na instrumentach cyfrowych;

- $\quad$ kryptoparty - wydarzenia, podczas których podejmowane są ważne tematy, jak na przykład bezpieczeństwo w sieci;

- $\quad$ slamy podróżnicze - wydarzenia poświęcone podróżom, podczas których w 10 minut można opowiedzieć o swoich podróżach, wyprawach;

- grupowe testowanie gier komputerowych - wyniki testów publikowane są na blogu;

- $\quad$ przeciwdziałanie i walka $\mathrm{z}$ analfabetyzmem.

\section{Aktywizacja społeczności lokalnej (Biblioteka w Aarhus) ${ }^{10}$}

W trakcie planowania nowej siedziby biblioteki rozpoczęły się intensywne prace nad opracowaniem wizji, koncepcji i wartości, którymi powstała placówka miałaby się kierować. Wtedy też zapadła decyzja, że biblioteka będzie przede wszystkim przestrzenią dla ludzi, a nie dla książek. To właśnie mieszkańcy mieli decydować o tym, co będzie w ich bibliotece. Mieszkańców włączono w prace nad planowaniem nowej placówki poprzez: organizację paneli obywatelskich, grupy fokusowe, wywiady poszerzone w przestrzeni miejskiej oraz domach użytkowników, podczas których dzielono się propozycjami, ale także proszono użytkowników o ocenę nowych pomysłów i przedstawianie własnych. Tym samym planowana przestrzeń przestała być przestrzenią stricte biblioteczną, tylko stała się przestrzenią publiczną.

Biblioteka w Aarhus posłużyła się modelem 4D, aby stworzyć nowoczesne przestrzenie dla użytkowników. Punktem wyjścia było przyjęcie założenia, że w planowaniu przestrzeni najważniejsze nie są książki, tylko ludzie i ich aktywności:

1. Przestrzeń inspiracji - miejsce, w którym można rozwijać wyobraźnię, inspirować się, na przykład podłoga interaktywna dla dzieci.

2. Przestrzeń uczenia się - miejsce do formalnego i nieformalnego zdobywania wiedzy.

3. Przestrzeń spotkań - miejsca, w którym można się spotkać, pobyć w towarzystwie innych osób.

4. Przestrzeń działania - przestrzeń do działania, czyli miejsce, w którym się coś dzieje, gdzie kreujemy rzeczywistość, na przykład zaproszeni

\footnotetext{
${ }^{10}$ Ibidem.
} 
lokalni twórcy uczą użytkowników nowych umiejętności, ochotnicy uczą dzieci programowania robotów.

Poszczególne przestrzenie niejednokrotnie przenikają się, uzupełniają czy też pełnią różne funkcje jednocześnie.

\section{Kreatywność i aktywny public relations (Biblioteka w Köln, Biblioteka w Aarhus) ${ }^{11}$}

Biblioteki dzięki swojej ofercie przygotowanej zgodnie z najnowszymi trendami prowadzą ciekawą działalność public relations poprzez:

- $\quad$ korzystanie z nietypowych form wsparcia: wizerunek biblioteki pojawia się na markowych butelkach regionalnego wina, a biblioteka dostaje niewielką sumę od każdej sprzedanej butelki; zaprzyjaźniona restauracja sprzedaje dania pod nazwą „Czytający kurczak”, a biblioteka od każdej sprzedanej porcji dostaje niewielką sumę pieniędzy;

- $\quad$ szukanie sponsorów i pozyskiwanie różnych form wsparcia, nie tylko środków finansowych, na przykład danie możliwości tworzenia kampanii PR zainteresowanym firmom, kierowanych do użytkowników biblioteki;

- funkcjonowanie specjalnych działów marketingu;

- zainteresowanie celebrytów, artystów;

- $\quad$ nagrywanie teledysków i filmów w budynku biblioteki;

- $\quad$ audycje promujące środowisko biblioteczne.

\section{Kreowanie przestrzeni otwartej (biblioteki duńskie)}

Otwarte biblioteki, czyli placówki działające przez określoną liczbę godzin bez obsady personelu to coraz bardziej popularny model wprowadzany w duńskim systemie bibliotecznym. Takie placówki pojawiły się blisko 10 lat temu, a pierwszą z nich była biblioteka w Vodskov. Obecnie coraz więcej bibliotek pracuje w systemie mieszanym: w części samoobsługowym, w części z bibliotekarzami. Najczęściej biblioteki pracują od godziny 9 do 22, akademickie do 24, przez większość czasu pracy użytkownicy muszą obsługiwać się sami, bibliotekarze pracują w ciągu tygodnia 20-21 godzin. Użytkownicy mogą dostać się na teren biblioteki miejskiej dzięki automatycznej weryfikacji kart ubezpieczenia zdrowotnego, których posiadaczami są wszyscy duńscy obywatele, a w bibliotekach akademickich legitymacji studenckiej czy pracowniczej $^{12}$.

\footnotetext{
${ }^{11}$ Ibidem.

${ }^{12}$ K. Boelt, Open libraries in Aalborg - a great success, „Scandinavian Library Quarterly” 2015, vol. 48, no 1-2, slq.nu/?article=volume-48-no-1-2-2015-19, [dostęp: 20.07.2016].
} 


\section{Inwestycja w młodych (biblioteka w Delft) ${ }^{13}$}

W wyniku zachodzących zmian, cięć budżetowych i odejścia znacznej liczby dorosłych użytkowników biblioteka w Delft postanowiła przemodelować się i skierować całą energię na dzieci w wieku do 14 lat oraz ich rodziców.

Misją biblioteki na lata 2015-2020 jest wpływanie na środowisko życia i uczenia się dzieci oraz zachęcanie do poznawania świata przez zabawę z wykorzystaniem wyobraźni i kreatywności. Kierując się powyższymi tezami biblioteka organizuje dla dzieci (przy udziale rodziców):

- $\quad$ kreatywny plac zabaw;

- teatr cieni, w którym dzieci mogą bawić się specjalnie przygotowanymi marionetkami;

- $\quad$ godziny czytania w różnych językach (hiszpański, francuski, angielski);

- godziny czytania przez ojców pod nazwą „Tata czyta dzieciom”;

- $\quad$ w przedszkolach - czytanie interaktywne z dziećmi;

- $\quad$ w ośrodkach opiekuńczych - przekazanie zbiorów książek, które dzieci mogą czytać z nauczycielami, wychowawcami;

- $\quad$ w środowiskach domowych - wolontariusz odwiedza dziecko w domu przez 15 tygodni, przychodzi na godzinę w tygodniu do jego domu, czyta z nim bajki, pokazuje rodzicom jak to można robić w ciekawy sposób, przy czym nie chodzi tu tylko o czytanie, ale również zabawę;

- $\quad$ w szkołach - organizowanie biblioteki szkolnej, aranżacja całego pomieszczenia, swoistego pokoju dziennego z książkami, komputerami, iPodami, wygodnymi meblami, $\mathrm{w}$ tych pomieszczeniach organizowane są również zajęcia prowadzone przez wolontariuszy, w tym praca indywidualna z uczniem słabszym;

- testowanie CoderDojo - międzynarodowego systemu, dzięki któremu młodzież przez zabawę i doświadczenie uczy się podstaw programowania;

- $\quad$ testowanie Green Screenu - zajęcia dla dzieci i młodzieży polegające na testowaniu zielonego ekranu, dzięki któremu można nagrywać scenki, historie w całkiem innej, niejednokrotnie bajkowej przestrzeni.

\section{Biblioteka dla wszystkich (biblioteki fińskie)}

Instytucje kierują się standardami, wśród których najważniejsze zasady to:

- $\quad$ biblioteka otwarta dla wszystkich;

- $\quad$ w bibliotece wszyscy są mile widziani;

\footnotetext{
${ }^{13}$ Nowe koncepcje-nowe biblioteki...
} 
- $\quad$ biblioteka ma spowodować, że ludziom żyje się lepiej;

- $\quad$ ludzie potrzebują siebie wzajemnie;

- $\quad$ kultura dostępna dla wszystkich.

W związku z tym biblioteki fińskie kładą nacisk na działania z partnerami i rozwój społeczeństwa obywatelskiego, które bardzo mocno identyfikuje się z placówką.

Najstarszą i największą biblioteką naukową w Finlandii jest Biblioteka Narodowa, pełniącą również rolę biblioteki uniwersyteckiej. Dzięki jej staraniom powstało konsorcjum FinELib, które zainicjowało powstanie Elektronicznej Biblioteki Narodowej. Obecnie FinELib skupia blisko 100 bibliotek różnego typu: uniwersyteckich, politechnicznych, publicznych czy instytutów naukowych. Konsorcjum jest odpowiedzialne za pozyskiwanie dla bibliotek i instytutów badawczych licencji użytkowników dla fińskich i międzynarodowych dokumentów elektronicznych. FinELib jest głównym dostawcą materiałów elektronicznych na uczelniach w Finlandii i oferuje około 30000 tytułów czasopism online i 300 referencyjnych baz danych, słowników i temu podobnych. Biblioteka Narodowa pełni również rolę centrum serwisowego dla wszystkich bibliotek fińskich, zapewniając wspólne usługi dla bibliotek różnego typu (naukowych, uniwersyteckich, publicznych i specjalnych). Fińskie biblioteki akademickie mają jednolity system biblioteczny, co sprawia, że użytkownikom łatwiej jest korzystać z niego przy wyszukiwaniu informacji w różnych bibliotekach. Dodatkowe wspólne finansowanie z ministerstwa pozwala kupować czasopisma i książki elektroniczne oraz usługi dla całego środowiska naukowego. Takie działania pozwalają na ekonomiczne wykorzystywanie środków finansowych i racjonalne pozyskiwanie materiałów do pracy naukowej $\mathrm{w}$ społeczeństwie informacyjnym ${ }^{14}$.

W bibliotekach można nie tylko wypożyczyć potrzebne materiały, ale miło spędzić czas. Biblioteki oferują między innymi:

- kursy tańca;

- $\quad$ kursy obsługi komputera i programów komputerowych;

- możliwość wypożyczenia instrumentu muzycznego;

- $\quad$ nagrania utworu w specjalnie przystosowanym studiu nagrań;

- możliwość przegrania na nowoczesne nośniki (za niewielką opłatą) zawartości prywatnych taśm magnetofonowych, kaset VHS czy płyt winylowych;

${ }^{14}$ S. Mądro, Analiza porównawcza fińskiej Biblioteki Narodowej (Biblioteki Uniwersytetu w Helsinkach) oraz polskiej Biblioteki Narodowej, http://eprints.rclis.org/24266/, [dostęp: 16.03.2017]. 
- bezpłatną wypożyczalnię rowerów;

- $\quad$ przestrzenie do zabawy dla najmłodszych.

Jak bardzo biblioteki są elementem fińskiego krajobrazu, niech świadczy fakt, że jedna $\mathrm{z}$ filii biblioteki $\mathrm{w}$ Tampere mieści się $\mathrm{w}$ centrum handlowym, a nowa biblioteka uniwersytecka w Helsinkach powstała na miejscu galerii handlowej ${ }^{15}$.

\section{Biblioteka gwarancją sukcesu (biblioteka Uniwersytetu Heriot-Watt w Edynburgu)}

Głównym celem działalności biblioteki Uniwersytetu Heriot-Watt jest doradztwo i wsparcie eksperckie w zakresie pozyskiwania przez pracowników i studentów niezbędnej wiedzy do pracy naukowej i studiowania. Biblioteka uniwersytecka oferuje studentom i naukowcom 716 indywidualnych i zbiorowych miejsc pracy, bezpośredni dostęp do około 150000 książek drukowanych, 50000 czasopism elektronicznych, 71000 książek elektronicznych i 270 baz. Biblioteka jest rozmieszczona na 4 piętrach i podzielona na trzy strefy: zieloną - przeznaczoną do pracy w grupach, pomarańczową - do cichej pracy zespołowej i strefę czerwoną - przeznaczoną do cichej pracy. Studenci mają do dyspozycji 7 pokoi pracy grupowej, wyposażonych w zależności od potrzeb, w specjalnie zaprojektowane meble, komputery sieciowe, monitory wiszące czy urządzenia projekcyjne. Do pracy indywidualnej przeznaczonych jest 21 pokoi jednoosobowych. Do dyspozycji studentów są stanowiska komputerowe z dostępem do baz i katalogów bibliotecznych, self-checks oraz urządzenia wielofunkcyjne. Na terenie biblioteki, jak i całego kampusu, jest dostęp do bezprzewodowego Internetu. Oferta biblioteki nie różniłaby się od oferty innych nowoczesnych bibliotek europejskich, gdyby nie jeden, ale zasadniczy szczegół. W 2015 r. biblioteka pozyskała środki na swoje unowocześnienie, ale przede wszystkim na stworzenie dodatkowych miejsc pracy dla studentów, gdyż tych ciągle brakuje. Dowodem na znaczenie usług bibliotecznych są słowa jednego z pracowników biblioteki, że studenci wiedzą, iż istnieje prosta zależność: im więcej czasu spędzonego w bibliotece tym lepsze oferty pracy po ukończeniu studiów.

${ }^{15}$ Biblioteka uniwersytecka $w$ Helsinkach. Ceglana brama wiedzy, http://www.bryla.pl/ bryla/1,85298,15518124,Biblioteka_uniwersytecka_w_Helsinkach_Ceglana_brama.html, [dostęp: 16.03.2017]. 


\section{Podsumowanie}

Nowoczesne europejskie biblioteki stały się miejscami, które są niezmiernie kreatywne i ciekawe. Do korzystania z ich usług zachęcają wyremontowane, często designerskie wnętrza, profesjonalna oraz wzorowana na obecnych trendach technologicznych oferta dla osób w różnym wieku. Konieczne jest całkowite zorientowanie na użytkownika, niesamowita elastyczność w projektowaniu i wykorzystywaniu powierzchni bibliotecznych oraz oferowanych usług, niekoniecznie stricte bibliotecznych, a także ciągłe poszukiwanie nowych kanałów komunikacji. Zdecydowany nacisk należy położyć na dbałość o integrowanie i aktywizowanie społeczności lokalnej, bo w tym należy upatrywać szans na dalsze funkcjonowanie bibliotek. Nowe wyzwania wymagają zaangażowania i kreatywności pracowników bibliotek oraz zdecydowanego odejścia od wizerunku bibliotekarza udostępniającego zbiory, czy to tradycyjne, czy elektroniczne, na rzecz animatora kultury, a nawet człowieka renesansu.

\section{Bibliografia}

Biblioteka uniwersytecka w Helsinkach. Ceglana brama wiedzy, http://www.bryla.pl/ bryla/1,85298,15518124,Biblioteka_uniwersytecka_w_Helsinkach_Ceglana_ brama.html, [dostęp: 16.03.2017].

Boelt K., Open libraries in Aalborg - a great success, „Scandinavian Library Quarterly" 2015, vol. 48, no 1-2, slq.nu/?article=volume-48-no-1-2-2015-19, [dostęp: 20.07.2016].

Liu Y.Q., Briggs S., A library in the palm of your hand: mobile services in top 100 university libraries, „Information Technology and Libraries” 2015, vol. 34, no 2, https://ejournals.bc.edu/ojs/index.php/ital/article/view/5650/pdf, [dostęp: 26.08. 2016].

Mądro S., Analiza porównawcza fińskiej Biblioteki Narodowe Biblioteki Uniwersytetu w Helsinkach) oraz polskiej Biblioteki Narodowej, http://eprints.rclis.org/24266/, [dostęp: 16.03.2017].

Mainka A., Hartmann S., Orszullok L., Peters I., Stallman A., Stock W. G., Public libraries in the Knowledge Society: core services of libraries in Informational World Cities, „Libri” 2013, vol. 63, no 4, s. 295-319.

McArthur J.A., Graham V.J., User-experience design and library spaces: a pathway to innovation?, „Journal of Library Innovation” 2015, vol. 6, no 2, s. 1-14.

Morales M., New State of America's Libraries Report finds shift in role of U.S. libraries, www.ala.org/news/press-releases/2015/04/new-state-america-s-libraries-repo rt-finds-shift-role-us-libraries, [dostęp: 16.04.2016].

Nguyen C., Les bibliothèques universitaires se désabonnent, „Documentalist - Sciences de l'information" 2014, vol. 51, no 3, s. 9-11. 
Nowe koncepcje - nowe biblioteki. Praktyczne przyklady z czterech krajów europejskich, http://www.instytutksiazki.pl/upload/Files/bnowaII_warszawa_podumowa nie.pdf, [dostęp: 16.03.2017].

Schopfel J., Roche J., Hubert G., Co-working and innovation: new concepts for academic libraries and learning centres, „New Library World” 2015, vol. 116, no $1 / 2$, s. 67-78.

Yi Z., Effective techniques for the promotion of library services and resources, "Information Research" 2016, vol. 21, no 1, s. 702, http://www.informationr.net/ ir/21-1/paper702.html\#.WP3P_qI3lw4, [dostęp: 16.03.2017]. 